\title{
Vorapaxar stabilizes permeability of the endothelial barrier under cholesterol stimulation via the AKT/JNK and NF-кB signaling pathways
}

\author{
JIANLIANG PANG ${ }^{1}$, PEIYANG HU ${ }^{2}$, JUNWEI WANG $^{3}$, JINSONG JIANG ${ }^{4,5}$ and JIFU LAI ${ }^{4,5}$ \\ Departments of ${ }^{1}$ Vascular Surgery, ${ }^{2}$ Surgery and ${ }^{3}$ Internal Medicine, Tiantai People's Hospital of Zhejiang Province, Taizhou, \\ Zhejiang 317200; ${ }^{4}$ Department of Vascular Surgery, Zhejiang Provincial People's Hospital; ${ }^{5}$ Department of Vascular Surgery, \\ People's Hospital of Hangzhou Medical College, Hangzhou, Zhejiang 310014, P.R. China
}

Received August 22, 2018; Accepted March 15, 2019

DOI: $10.3892 / \mathrm{mmr} .2019 .10211$

\begin{abstract}
Atherosclerosis (AS) is an inflammatory disease that occurs in the arterial wall and is characterized by progressive lipid accumulation within the intima of large arteries, leading to the dysfunction of endothelial cells and further destruction of the endothelial barrier and vascular tone. Arterial intima injury accelerates the adhesion and activation of platelets at the injury site. The activation of platelets results in the secretion of growth factors, leading to the migration and proliferation of vascular smooth muscle cells (VSMCs), promoting the formation of plaque, resulting in the formation of thrombus. The present study found that vorapaxar could alleviate the inflammatory response induced by a high concentration of cholesterol stimulation and increase the release of nitric oxide (NO) via the protein kinase B (AKT) signaling pathway and regulation of the intracellular concentration of $\mathrm{Ca}^{2+}\left(\left[\mathrm{Ca}^{2+}\right]_{\mathrm{i}}\right)$. We also found that vorapaxar could reduce the damage of DNA caused by cholesterol stimulation and regulate the cell cycle via the AKT/JNK signaling pathway and its downstream molecules glycogen synthase kinase $3 \beta$ (GSK-3 $\beta$ ) and connexin 43 , maintaining the integrity of the endothelial barrier and proliferation of endothelial cells, serving a protective role in endothelial cells.
\end{abstract}

Correspondence to: Dr Jifu Lai, Department of Vascular Surgery, Zhejiang Provincial People's Hospital, 158 Shangtang Road, Hangzhou, Zhejiang 310014, P.R. China

E-mail: lai758258@163.com; lai_jifu2018@outlook.com

Abbreviations: AS, atherosclerosis; VSMCs, vascular smooth muscle cells; AKT, protein kinase B; GSK-3 $\beta$, glycogen synthase kinase $3 \beta ;\left[\mathrm{Ca}^{2+}\right]_{i}$, intracellular concentration of $\mathrm{Ca}^{2+}$; PARs, protease-activated receptors; eNOS, endothelial nitric oxide synthase; CVD, cardiovascular disease

Key words: vorapaxar, endothelial barrier, cholesterol, proteaseactivated receptors

\section{Introduction}

Platelets, first identified over 130 years ago, are produced by megakaryocytes in bone marrow and lungs, and are critical for maintaining hemostasis and thrombosis balance (1). In physiological status, the coagulation system is strictly regulated, but under pathological status, platelet activation leads to the formation of occlusive thrombus and causes myocardial infarction and stoke, especially in patients with hyperlipidemia (2). When the integrity of blood vessels is destroyed by injury, atherosclerotic plaque formation or inflammatory reaction, platelets clot together and form a thrombus at the site of injury. The flow rate of platelets is reduced in pathological status by the complex of glycoprotein and von Willebrand factor (vWF), and the release of thromboxane 2 (TXA2), adenosine diphosphate (ADP) and 5-hydroxytryptamine (5-HT) accelerates the aggregation of platelets and formation of thrombus (3). Anti-platelet drugs are commonly administered to patients with a high risk of thrombogenesis, which can increase the risk of bleeding and the emergence of a resistance effect to drugs (4), and the application of anti-platelet drugs decreases the risk of thrombogenesis.

Anti-platelet drugs are divided into different groups according to their pharmacological mechanisms, including TXA2 receptor antagonists, P2Y12 antagonists, GP IIb/IIIa receptor antagonists and protease-activated receptor (PAR) inhibitors. PAR is expressed in most cell types in the vasculature. PARs contain four members, including PAR-1, PAR-2, PAR-3 and PAR-4. Among them, PAR-1 is a major effector in the thrombin signaling pathway and negatively regulates the permeability of the endothelial barrier (5). Antagonists to PARs are a newly found group of anti-platelet drugs and could specifically bind with PARs and inhibit the activation of platelets. Multi-center clinical trial results have shown that patients are able to tolerate PARs well, and the risk of bleeding does not increase even when combined with aspirin and clopidogrel (6). The endothelial barrier is an important component of blood vessels, and the permeability of the endothelial barrier is transiently increased in the process of thrombogenesis. The aggregation of platelets induces the release of thrombin, further activating PAR1 and increasing 
the activity of phospholipase $\mathrm{C}$, resulting in activation of the protein kinase $\mathrm{C}$ (PKC) signaling pathway (7). In addition, a previous study found that multiple factors could inhibit the expression level of endothelial nitric oxide synthase (eNOS), such as aging, obesity and disease, including cholesterol, resulting in the reduction of nitric oxide (NO) (8). This effect is mediated by the phosphatidylinositide 3 -kinase (PI3K)/AKT signaling pathway in endothelial cells and leads to increased permeability of the endothelial barrier (9). However, the detailed mechanism of vorapaxar in sustaining homeostasis of the endothelial barrier under high lipid stimulation is not fully understood.

In the present study, we found that high lipid stimulation reduced the proliferation of endothelial cells, and vorapaxar alleviated this effect via increasing the intracellular $\mathrm{Ca}^{2+}$ concentration, activation of the $\mathrm{AKT} / \mathrm{JNK}$ signaling pathway and inhibition of the inflammatory response, resulting in maintenance of permeability of the endothelial barrier and presenting a protective effect on endothelial cells.

\section{Materials and methods}

Materials. Gibco ${ }^{\mathrm{TM}}$ high glucose Dulbecco's modified Eagle's medium (H-DMEM) (10569044) and fetal bovine serum (FBS) (10099141) were obtained from Thermo Fisher Scientific, Inc. (Waltham, MA, USA). Cholesterol (C8667) was purchased from Sigma-Aldrich (Merck KGaA, Darmstadt, Germany). Thrombin receptor activator peptide 6 (TRAP-6, HY-P0078) and vorapaxar (HY-10119) were obtained from MedChemExpress (MCE, Monmouth Junction, NJ, USA). MTT (IM0280) was purchased from Beijing Solarbio Science and Technology Co., Ltd. (Beijing, China). Anti-JNK (ab179461), p-JNK (ab124956), AKT (ab8805), p-AKT (ab38449), eNOS (ab76198), NF-кB (ab16502), ATM (ab78), p-ATM (ab81292), ATR (ab101900), p-ATR (ab178407), GSK3 $\beta$ (ab32391), p-GSK3 $\beta$ (ab68476), Connexin 43/GJA1 (ab11370) and GAPDH (ab8245) antibodies were purchased from Abcam (Cambridge, UK). Cell membrane permeable calcium fluorescent probe (40704ES50), Total RNA extraction reagent (10606ES60), First Strand cDNA Synthesis SuperMix (11141ES10), and qPCR SYBR-Green Master Mix (11203ES03) were purchased from Shanghai Yeasen Biotechnology (Shanghai, China). Protease inhibitor cocktail (CW2200) and phosphatase inhibitor cocktail (CW2383) were purchased from CWBio (Beijing, China). Anti-rabbit and anti-mouse HRP-labeling secondary antibodies (10147552 and 10145703) were obtained from KPL, Inc. (Gaithersburg, MD, USA).

Cell culture. EA.hy926 cells (GNHu39) were purchased from the Cell Bank of the Type Culture Preservation Committee of the Chinese Academy of Sciences (Shanghai, China) and cultured in a humidified $5 \% \mathrm{CO}_{2}$ atmosphere at $37^{\circ} \mathrm{C}$ in H-DMEM containing $10 \%$ FBS. The cells were divided into four groups when cell confluence reached $60-70 \%$, including a control (NC) group, cholesterol stimulation $(\mathrm{CH})$ group, cholesterol stimulation with TRAP-6 treatment $(\mathrm{CH}+\mathrm{T})$ group and cholesterol stimulation with vorapaxar treatment $(\mathrm{CH}+\mathrm{V})$ group. Cholesterol was dissolved in dimethyl sulfoxide (DMSO) at a concentration of $100 \mathrm{mmol} / \mathrm{l}$ (10), and cells were treated with TRAP- 6 for $5 \mathrm{~min}$ and vorapaxar for $1 \mathrm{~h}$ before cholesterol stimulation. After being treated with cholesterol for $24 \mathrm{~h}$, the cells were collected for the further experiments.

MTT assays. Cells were first washed with sterile phosphate-buffered saline (PBS) to remove redundant cholesterol, and an MTT assay was performed according to a previous study (10). Briefly, cells were grouped as previously described and seeded into each well of 96-well plates. Each group of cells was first treated with different concentrations of cholesterol for $24 \mathrm{~h}$, different concentration of TRAP-6 for $5 \mathrm{~min}$ and different concentration of vorapaxar for $1 \mathrm{~h}$ (11), followed by incubation with $5 \mathrm{mg} / \mathrm{ml} \mathrm{MTT}$ for $3 \mathrm{~h}$. After incubation, the optical density at $490 \mathrm{~nm}$ was measured with a SpectraMax Series microplate reader (Molecular Devices, Sunnyvale, CA, USA). The viability rate was calculated as: $\left(\mathrm{OD}_{\text {Treatment }}-\mathrm{OD}_{\text {Blank }}\right) /\left(\mathrm{OD}_{\text {Control }}-\mathrm{OD}_{\text {Blank }}\right)$.

Extraction of nuclear proteins. Nuclear protein extraction was performed according to a previous study (12). Briefly, cells were divided into four groups when cell confluence reached 60-70\%, including a control (NC) group, a cholesterol stimulation $(\mathrm{CH})$ group, a cholesterol stimulation with TRAP-6 treatment $(\mathrm{CH}+\mathrm{T})$ group and a cholesterol stimulation with vorapaxar treatment $(\mathrm{CH}+\mathrm{V})$ group. Cells were treated with TRAP- 6 for $5 \mathrm{~min}$ and vorapaxar for $1 \mathrm{~h}$ before cholesterol stimulation. After being treated with cholesterol for $24 \mathrm{~h}$, cells were washed with sterile PBS to remove extra cholesterol. Then, cells were lysed with lysis buffer A (10 mmol/1 HEPES $\mathrm{pH}$ 7.9, $10 \mathrm{mmol} / \mathrm{l} \mathrm{KCl}, 0.1 \mathrm{mmol} / 1$ EDTA, $0.1 \mathrm{mmol} / 1$ EGTA, $0.5 \% \mathrm{NP}-40,1 \mathrm{mmol} / 1 \mathrm{DTT}$ and protease inhibitor), and the supernatants were collected after centrifugation at $13,523 \mathrm{x} \mathrm{g}$ for $10 \mathrm{~min}$. Then, the pellets were lysed with lysis buffer $\mathrm{B}$ [20 mmol/1 HEPES (pH 7.9), $0.4 \mathrm{~mol} / 1 \mathrm{NaCl}, 1 \mathrm{mmol} / 1$ EDTA, $1 \mathrm{mmol} / 1 \mathrm{EGTA}, 1 \mathrm{mmol} / 1 \mathrm{DTT}$ and protease inhibitor] for $30 \mathrm{~min}$. The supernatants were collected after centrifugation at $20,238 \mathrm{x}$ g for $15 \mathrm{~min}$. The concentration of proteins was measured with a BCA assay.

Western blotting. Cells were divided into four groups when cell confluence reached $60-70 \%$, including a control (NC) group, a cholesterol stimulation $(\mathrm{CH})$ group, a cholesterol stimulation with TRAP-6 treatment (CH+T) group and a cholesterol stimulation with vorapaxar treatment $(\mathrm{CH}+\mathrm{V})$ group. Cells were treated with TRAP- 6 for $5 \mathrm{~min}$ and vorapaxar for $1 \mathrm{~h}$ before cholesterol stimulation. After being treated with cholesterol for $24 \mathrm{~h}$, cells were washed with sterile PBS to remove extra cholesterol. Then, the cells in each group were collected and lysed with urea lysis buffer (8 M urea, $10 \mathrm{mM}$ DTT, $50 \mathrm{mM}$ IAA, cocktail protease inhibitors and phosphatase inhibitor cocktail) at $4^{\circ} \mathrm{C}$, followed by ultrasonic lysis. The supernatant in each group was collected after centrifugation at $13,523 \mathrm{x} \mathrm{g}$ for $10 \mathrm{~min}\left(4^{\circ} \mathrm{C}\right)$. The concentration of protein was determined using a BCA assay. Protein samples were firstly balanced with GAPDH, and $60 \mu \mathrm{g}$ of each protein sample was loaded and separated using 10\% SDS-PAGE. After electrophoresis, the samples were transferred onto $0.22-\mu \mathrm{m}$ nitrocellulose membranes using a semi-dry electro blotter. The membranes were first incubated with a primary antibody $(1: 1,000)$ overnight at $4^{\circ} \mathrm{C}$ and then incubated with the corresponding secondary antibody $(1: 5,000)$ for $1 \mathrm{~h}$ at room temperature. 
After being balanced with GAPDH, protein samples in each group were homogeneously mixed and sub-packaged in each individual tube as each sample was used in performing the western blot analysis of GAPDH and stored at $-80^{\circ} \mathrm{C}$ until performing the following analysis. Then, western blot analysis of 12 target proteins were performed individually in 12 individual SDS-PAGE electrophoresis. After electrophoresis, proteins were transferred onto nitrocellulose membranes and incubated with antibodies as described above. Proteins were detected using ECL immunoblotting reagent and normalized with GAPDH. Gray values of each band were quantified using Scion Image software (version 4.0.3.2; Scion Corp., Frederick, MD, USA). Experiments were repeated for three times.

Extraction of cellular total RNA and quantitative real-time PCR analysis for target gene expression. Extraction of total RNA was performed according to the protocol. Briefly, cells were lysed with total RNA extraction reagent and centrifuged at $12,000 \mathrm{x} \mathrm{g}$ for $15 \mathrm{~min}$ after chloroform was added. Then, isopropanol was added to the water phase, and the reaction was incubated at room temperature for $10 \mathrm{~min}$. After ethanol was added and centrifugation at 7,500 $\mathrm{x}$ g for $5 \mathrm{~min}$, total RNA was in the pellet. Reverse transcription was performed according to the protocol. Quantitative real-time PCR was performed after the cDNA was synthesized. The primer sequences are listed as follows: IL-1 $\beta$ : Forward, 5'-CAGAGAGTCCTGTGCTG AAT-3' and reverse, 5'-GTAGGAGAGGTCAGAGAGGC-3'; TNF- $\alpha$ : Forward, 5'-TCTCGAACCCCGAGTGACAA-3' and reverse, 5'-TATCTCTCAGCTCCACACCA-3'; IL-8: Forward, 5'-ATGACTTCCAAGCTGGCCGTG-3' and reverse, 5'-CTC TTCAAAAACTTCTCCCGACTCTTAAGTATT-3'; IL-13: Forward, 5'-CACCATGCATCCGCTCCTCAATCCT-3' and reverse, 5'-GTTGAACTGTCCCTCGCGAAA-3'. The annealing temperature was set at $55^{\circ} \mathrm{C}$ and the reaction was repeated for 40 cycles. The threshold cycle (CT) was calculated with normalized fluorescence signal after generation of real-time amplification. The CT value was proportional with the initial number in the sample of target copies and was used to perform the kinetic analysis. The quantity of the target gene in the starting sample was measured after comparison with the CTs of the positive control in a serial dilution. Relative analysis on expression of each gene was performed using $2^{-\Delta \Delta \mathrm{Cq}}$ method according to previous study (13). The transcripts of GAPDH were used as an internal reference, and the quantification of clustering mRNA was normalized with relative GAPDH mRNA.

Detection of $\left[\mathrm{Ca}^{2+}\right]_{i}$ using immunofluorescence. The concentration of intercellular $\mathrm{Ca}^{2+}\left(\left[\mathrm{Ca}^{2+}\right]_{\mathrm{i}}\right)$ was evaluated according to the protocol of the cell membrane permeable calcium fluorescent probe. Briefly, $1 \times 10^{4}$ cells in each groups were seeded into the confocal plate, cells were cultured as previously described in the cell culture method section above, and no more specific endothelial cell growth factors were added. And then, cells were grouped and treated as previously described in cell culture section above. Following treatment, the medium was removed and the cells were incubated with $4 \mu \mathrm{mol} / 1$ Fluo-4 at $37^{\circ} \mathrm{C}$ for $30 \mathrm{~min}$. Then, the cells were washed with PBS three times. Images were acquired using confocal microscopy (objective, 20x; Leica TCS SP8; Leica Microsystems GmbH,
Wetzlar, Germany) and analyzed using IPP 6.0 software (Media Cybernetics, Inc., Rockville, MD, USA).

Statistical analysis. The data are displayed as means \pm SEM. Each experiment was repeated three times independently. One-way analysis of variance (ANOVA) was used to analyze the differences between groups using the GraphPad Prism 7.0 software (GraphPad Software, Inc., La Jolla, CA, USA) followed with Tukey's post-hoc test. P-value $<0.05$ was set as a statistically significant difference.

\section{Results}

Effect of cholesterol on the proliferation of endothelial cells. As shown in Fig. 1A, the viability rates following treatment with different concentrations of cholesterol were $92.6 \pm 3.8$, $68.3 \pm 2.4$ and $59.1 \pm 1.4$ in the 50,100 and $200 \mathrm{mmol} / \mathrm{l}$ cholesterol treatment groups, respectively. The viability rate was significantly decreased in the 100 and $200 \mathrm{mmol} / 1$ cholesterol treatment groups compared with the $\mathrm{NC}$ group $(\mathrm{P}=0.001$ and $\mathrm{P}<0.001)$. As shown in Fig. $1 \mathrm{~B}$, the viability rates were $92.1 \pm 3.4,89.2 \pm 3.8,73.2 \pm 3.6$ and $61.1 \pm 2.7$ for the 10,20 , 40 and $60 \mu \mathrm{M}$ TRAP- 6 treatment groups after $5 \mathrm{~min}$. The viability rate was significantly increased in the 20,40 and $60 \mu \mathrm{M}$ TRAP- 6 treatment groups compared with the NC group $(\mathrm{P}=0.044, \mathrm{P}=0.002$ and $\mathrm{P}<0.001)$. As shown in Fig. $1 \mathrm{C}$, the viability rates were $95.3 \pm 4.9,118.4 \pm 6.2$ and $116.3 \pm 5.5$ in the 20,50 and $80 \mu \mathrm{M}$ vorapaxar treatment groups. The viability rate was significantly increased in the 50 and $80 \mu \mathrm{M}$ vorapaxar treatment groups compared with the $\mathrm{NC}$ group $(\mathrm{P}=0.018$ and 0.020). After treatment with $100 \mathrm{mmol} / \mathrm{l}$ cholesterol for $24 \mathrm{~h}$, we detected the viability rate using an MTT assay (Fig. 1D). The viability rate was $65.2 \pm 3.2$ in the $\mathrm{CH}$ group, $82.3 \pm 2.3$ in the $\mathrm{CH}+\mathrm{V}$ group and $51.7 \pm 1.6$ in the $\mathrm{CH}+\mathrm{T}$ group. Cholesterol treatment significantly decreased the proliferation of endothelial cells compared with the NC group $(\mathrm{P}=0.002$ in the $\mathrm{CH}$ group), and vorapaxar treatment and TRAP- 6 treatment significantly increased or decreased the proliferation rate of the endothelial cells $(\mathrm{P}=0.0228$ in the $\mathrm{CH}+\mathrm{V}$ group and 0.001 in the $\mathrm{CH}+\mathrm{T}$ group). This result indicated that vorapaxar may serve an important role in the proliferation of endothelial cells.

Real-time quantification PCR was used to detect the expression levels of inflammation-related genes. Cholesterol is able to induce inflammation in endothelial cells, increasing the expression levels of inflammation-related genes. Herein, the expression levels of IL-1 $\beta$, TNF- $\alpha$, IL- 8 and IL-13 were detected. As shown in Fig. 2A and $\mathrm{C}$, the expression levels of IL-1 $\beta$ were $2.3 \pm 0.6,4.8 \pm 0.9,2.9 \pm 0.5$ and $5.6 \pm 0.7$ in the $\mathrm{NC}$ group, the $\mathrm{CH}$ group, the $\mathrm{CH}+\mathrm{V}$ group and the $\mathrm{CH}+\mathrm{T}$ group and expression levels of TNF- $\alpha$ were $0.8 \pm 0.2,2.2 \pm 0.4,1.6 \pm 0.5$ and $3.3 \pm 0.5$ in these groups. As shown in Fig. $2 \mathrm{~B}$ and $\mathrm{C}$, the expression levels of IL-8 were $1.7 \pm 0.3,3.5 \pm 0.4,2.6 \pm 0.3$ and $4.2 \pm 0.5$ in the $\mathrm{NC}$ group, the $\mathrm{CH}$ group, the $\mathrm{CH}+\mathrm{V}$ group and the $\mathrm{CH}+\mathrm{T}$ group, and $\mathrm{IL}-13$ levels were $3.1 \pm 0.4,1.5 \pm 0.2$, $2.6 \pm 0.4$ and $0.8 \pm 0.2$ in these groups. The expression level of IL-1 $\beta$ was significantly increased in the $\mathrm{CH}$ and the $\mathrm{CH}+\mathrm{T}$ group compared with the $\mathrm{NC}$ group $(\mathrm{P}=0.016$ in the $\mathrm{CH}$ group and 0.003 in the $\mathrm{CH}+\mathrm{T}$ group), and vorapaxar significantly decreased the expression level of IL-1 $\beta$ in the $\mathrm{CH}+\mathrm{V}$ group 

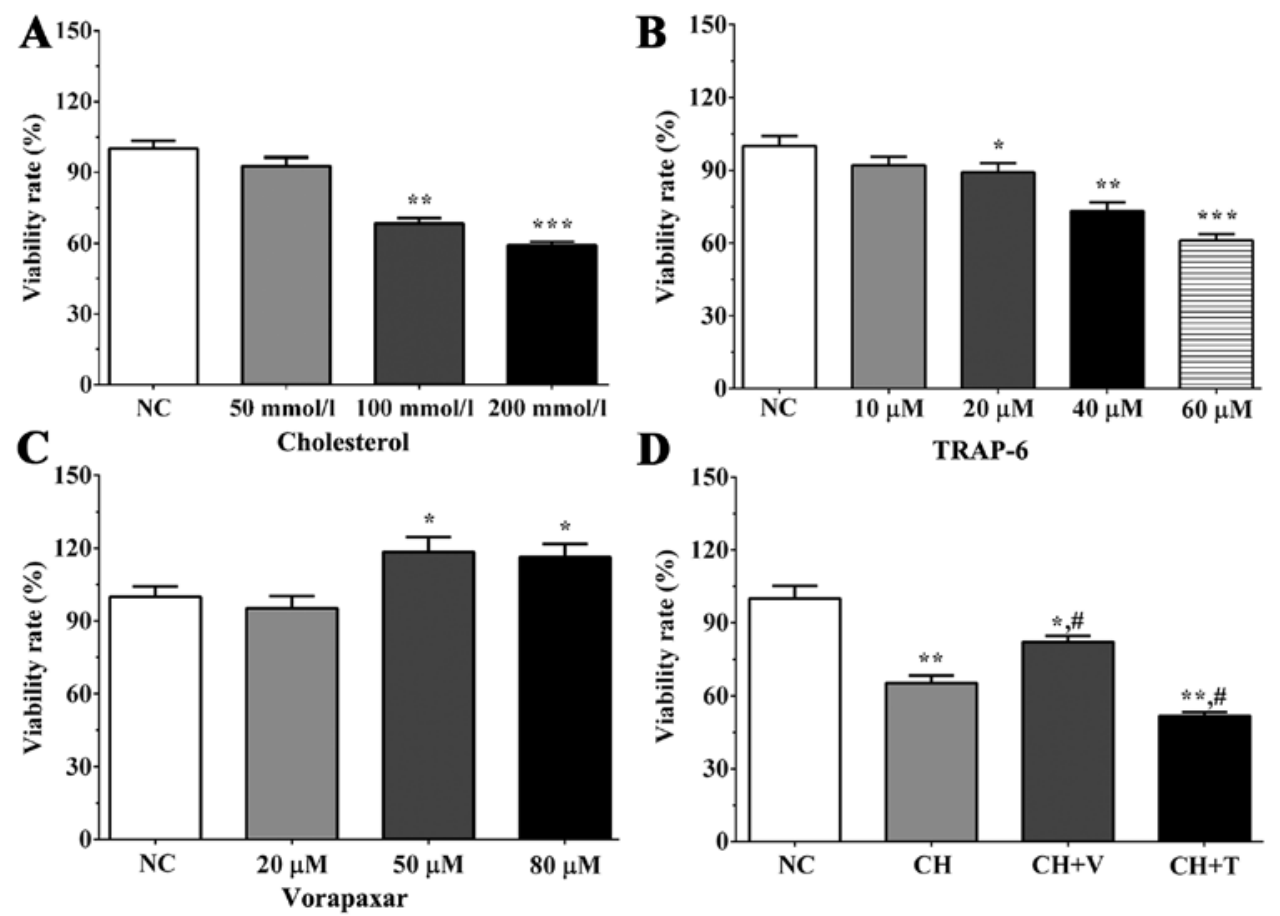

Figure 1. Effect of cholesterol, TRAP-6 and vorapaxar on proliferation of endothelial cells. (A) Viability rate of endothelial cells following stimulation with different concentrations of cholesterol. (B) Viability rate of endothelial cells following stimulation with different concentrations of TRAP-6. (C) Viability rate of endothelial cells following stimulation with different concentrations of vorapaxar. (D) Viability rate of endothelial cells in each treatment group. Experiments were repeated three times independently. Data are represented as the mean $\pm \mathrm{SEM}$. ${ }^{*} \mathrm{P}<0.05,{ }^{* *} \mathrm{P}<0.01$ and ${ }^{* * *} \mathrm{P}<0.001$ vs. the NC group; ${ }^{*} \mathrm{P}<0.05$ vs. the $\mathrm{CH}$ group. Groups: $\mathrm{NC}$, negative control group; $\mathrm{CH}$, a cholesterol stimulation group; $\mathrm{CH}+\mathrm{T}$, cholesterol stimulation with TRAP- 6 treatment group; $\mathrm{CH}+\mathrm{V}$, cholesterol stimulation with vorapaxar treatment group.
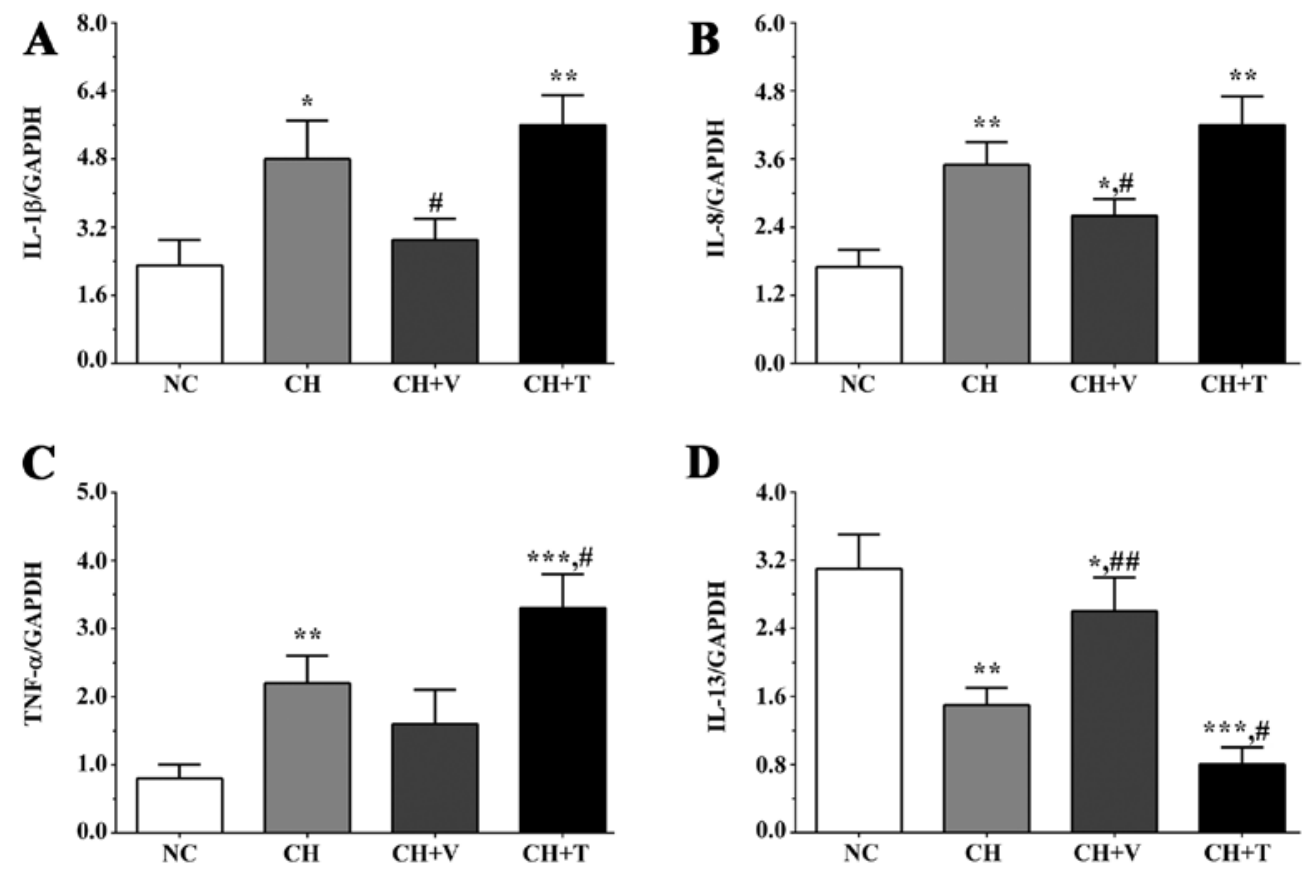

Figure 2. Expression levels of inflammation-related cytokines in each group using qPCR. (A) Expression level of interleukin (IL)-1 $\beta$ in each group. (B) Expression level of IL-8 in each group. (C) Expression level of tumor necrosis factor (TNF)- $\alpha$ in each group. (D) Expression level of IL-13 in each group. Experiments were repeated three times independently. Data are represented as the mean $\pm \mathrm{SEM}$. ${ }^{*} \mathrm{P}<0.05,{ }^{* * *} \mathrm{P}<0.01$ and ${ }^{* * * *} \mathrm{P}<0.001$ vs. the $\mathrm{NC}$ group; ${ }^{*} \mathrm{P}<0.05$ and ${ }^{\# \#} \mathrm{P}<0.01$ vs. the $\mathrm{CH}$ group. GAPDH was used as an internal control. Groups: $\mathrm{NC}$, negative control group; $\mathrm{CH}$, a cholesterol stimulation group; $\mathrm{CH}+\mathrm{T}$, cholesterol stimulation with TRAP-6 treatment group; $\mathrm{CH}+\mathrm{V}$, cholesterol stimulation with vorapaxar treatment group.

compared with the $\mathrm{CH}$ group $(\mathrm{P}=0.033)$. The expression levels of IL-8 were significantly increased in all cholesterol-treated groups compared with the $\mathrm{NC}$ group $(\mathrm{P}=0.003$ in the $\mathrm{CH}$ group, 0.021 in the $\mathrm{CH}+\mathrm{V}$ group and 0.002 in the $\mathrm{CH}+\mathrm{T}$ group), and 


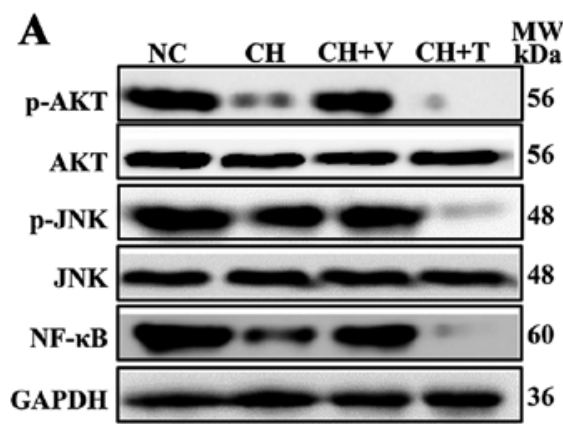

C

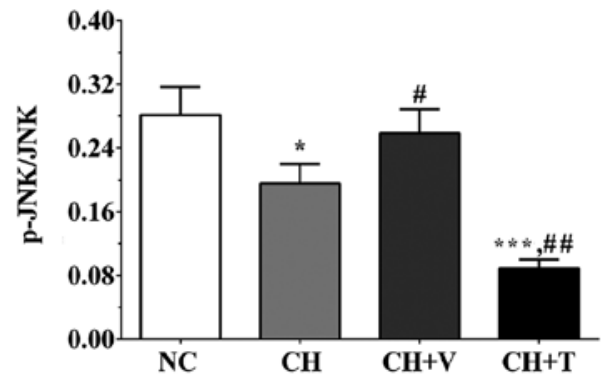

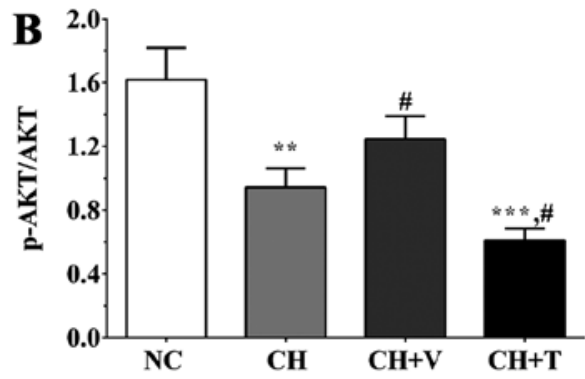

D

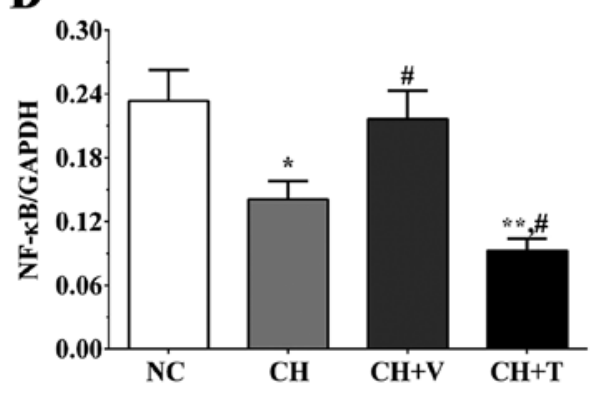

Figure 3. Expression levels of molecules in the AKT/JNK signaling pathway. (A) Detection of expression levels of p-AKT, AKT, p-JNK, JNK and NF- $\kappa$ B using western blotting. (B-D) Quantitative analysis of the western blot results. Experiments were repeated three times independently. Data are represented as the mean \pm SEM. ${ }^{*} \mathrm{P}<0.05,{ }^{* *} \mathrm{P}<0.01$ and ${ }^{* * *} \mathrm{P}<0.001$ vs. the $\mathrm{NC}$ group; ${ }^{\#} \mathrm{P}<0.05$ and ${ }^{\# \#} \mathrm{P}<0.01$ vs. the $\mathrm{CH}$ group. GAPDH was used as an internal control. Each image of the western blot band was separated using a black rectangle. Groups: NC, negative control group; $\mathrm{CH}$, a cholesterol stimulation group; $\mathrm{CH}+\mathrm{T}$, cholesterol stimulation with TRAP-6 treatment group; $\mathrm{CH}+\mathrm{V}$, cholesterol stimulation with vorapaxar treatment group.

vorapaxar significantly decreased the expression level of IL-8 in the $\mathrm{CH}+\mathrm{V}$ group compared with the $\mathrm{CH}$ group $(\mathrm{P}=0.036)$. The expression levels of TNF- $\alpha$ were significantly increased in the $\mathrm{CH}$ and the $\mathrm{CH}+\mathrm{T}$ groups compared with the $\mathrm{NC}$ group ( $\mathrm{P}=0.006$ in the $\mathrm{CH}$ group and 0.001 in the $\mathrm{CH}+\mathrm{T}$ group), and TRAP-6 treatment significantly increased this trend compared with the $\mathrm{CH}$ group ( $\mathrm{P}=0.041)$. However, the expression level of IL-13, an anti-inflammatory factor, presented a different trend. The expression level of IL-13 was significantly decreased after cholesterol treatment $(\mathrm{P}=0.003$ in the $\mathrm{CH}$ group, 0.046 in the $\mathrm{CH}+\mathrm{V}$ group and 0.001 in the $\mathrm{CH}+\mathrm{T}$ group), and vorapaxar or TRAP-6 significantly alleviated or increased this trend, respectively, compared with the $\mathrm{CH}$ group $(\mathrm{P}=0.008$ in the $\mathrm{CH}+\mathrm{V}$ group and 0.013 in the $\mathrm{CH}+\mathrm{T}$ group). These results indicated that cholesterol induced an inflammatory response in endothelial cells while vorapaxar inhibited this trend serving a protective role in endothelial cells.

Western blot analysis was used to detect the expression levels of molecules in the AKT/JNK signaling pathway. The expression levels of molecules in the AKT/JNK signaling pathway were evaluated using western blot analysis. As shown in Fig. $3 \mathrm{~A}$ and $\mathrm{C}$, the ratios of $\mathrm{p}-\mathrm{JNK} / \mathrm{JNK}$ were $0.28 \pm 0.04$, $0.19 \pm 0.02,0.24 \pm 0.03$ and $0.09 \pm 0.01$ in the $\mathrm{NC}$ group, the $\mathrm{CH}$ group, the $\mathrm{CH}+\mathrm{V}$ group and the $\mathrm{CH}+\mathrm{T}$ group. As shown in Fig. $3 \mathrm{~A}$ and $\mathrm{B}$, the ratios of p-AKT/AKT were $1.62 \pm 0.20$, $0.94 \pm 0.12,1.25 \pm 0.14$ and $0.61 \pm 0.08$ in these groups. As shown in Fig. $3 \mathrm{~A}$ and $\mathrm{D}$, the expression levels of NF- $\kappa \mathrm{B}$ were $0.23 \pm 0.03,0.14 \pm 0.02,0.22 \pm 0.03$ and $0.09 \pm 0.01$ in these groups The ratios of $\mathrm{p}-\mathrm{AKT} / \mathrm{AKT}, \mathrm{p}-\mathrm{JNK} / \mathrm{JNK}$ and $\mathrm{NF}-\kappa \mathrm{B}$ were significantly decreased in the $\mathrm{CH}$ group and the $\mathrm{CH}+\mathrm{T}$ group compared with the $\mathrm{NC}$ group $(\mathrm{P}=0.007,0.025$ and 0.012 in the $\mathrm{CH}$ group and $0.001,0.001,0.002$ in the $\mathrm{CH}+\mathrm{T}$ group) and were significantly increased in the $\mathrm{CH}+\mathrm{V}$ group compared with the $\mathrm{CH}$ group $(\mathrm{P}=0.044,0.046$ and 0.018$)$. The expression levels of these molecules were significantly decreased in the $\mathrm{CH}+\mathrm{T}$ group compared with the $\mathrm{CH}$ group $(\mathrm{P}=0.017,0.002$ and 0.018$)$. These results showed that the AKT/JNK signaling pathway and expression of NF- $\mathrm{NB}$ were inhibited in endothelial cells after cholesterol stimulation and that vorapaxar could reduce these inhibitory effects on activation of the AKT/JNK signaling pathway and expression of NF- $\kappa \mathrm{B}$, whereas TRAP-6 enhanced the inhibitory effects on activation of the AKT/JNK signaling pathway and expression of $\mathrm{NF}-\kappa \mathrm{B}$.

Western blot analysis was used to detect the expression levels of DNA damage- and cell cycle-related proteins. As shown in Fig. 4A-C, the ratios of p-ATM/ATM were $0.24 \pm 0.03,0.74 \pm 0.10,0.50 \pm 0.06,1.22 \pm 0.15$ in the NC group, the $\mathrm{CH}$ group, the $\mathrm{CH}+\mathrm{V}$ group and the $\mathrm{CH}+\mathrm{T}$ group, and the ratios of $\mathrm{p}-\mathrm{ATR} / \mathrm{ATR}$ were $0.27 \pm 0.03,0.62 \pm 0.08$, $0.54 \pm 0.07,1.13 \pm 0.14$ in these groups. The expression levels of cell cycle-related proteins were also detected in endothelial cells and the effect of cholesterol on the cell cycle was evaluated. As shown in Fig. 4A, D and F, the ratios of p-GSK $3 \alpha /$ GSK $3 \alpha$ were $0.84 \pm 0.10,0.32 \pm 0.04,0.47 \pm 0.06$ and $0.21 \pm 0.03$ in the $\mathrm{NC}$ group, the $\mathrm{CH}$ group, the $\mathrm{CH}+\mathrm{V}$ group and the $\mathrm{CH}+\mathrm{T}$ group, and the expression levels of cyclin D1 were $1.22 \pm 0.15,0.49 \pm 0.06,0.78 \pm 0.10$ and $0.35 \pm 0.04$ in these groups. As a downstream molecule of the AKT/JNK signaling pathway, eNOS serves an important role in NO synthesis and has an anti-atherosclerotic effect. As shown in Fig. 4E, the expression levels of eNOS were 1.38 \pm 0.17 , $0.61 \pm 0.08,0.93 \pm 0.12$ and $0.46 \pm 0.06$ in these groups. The 

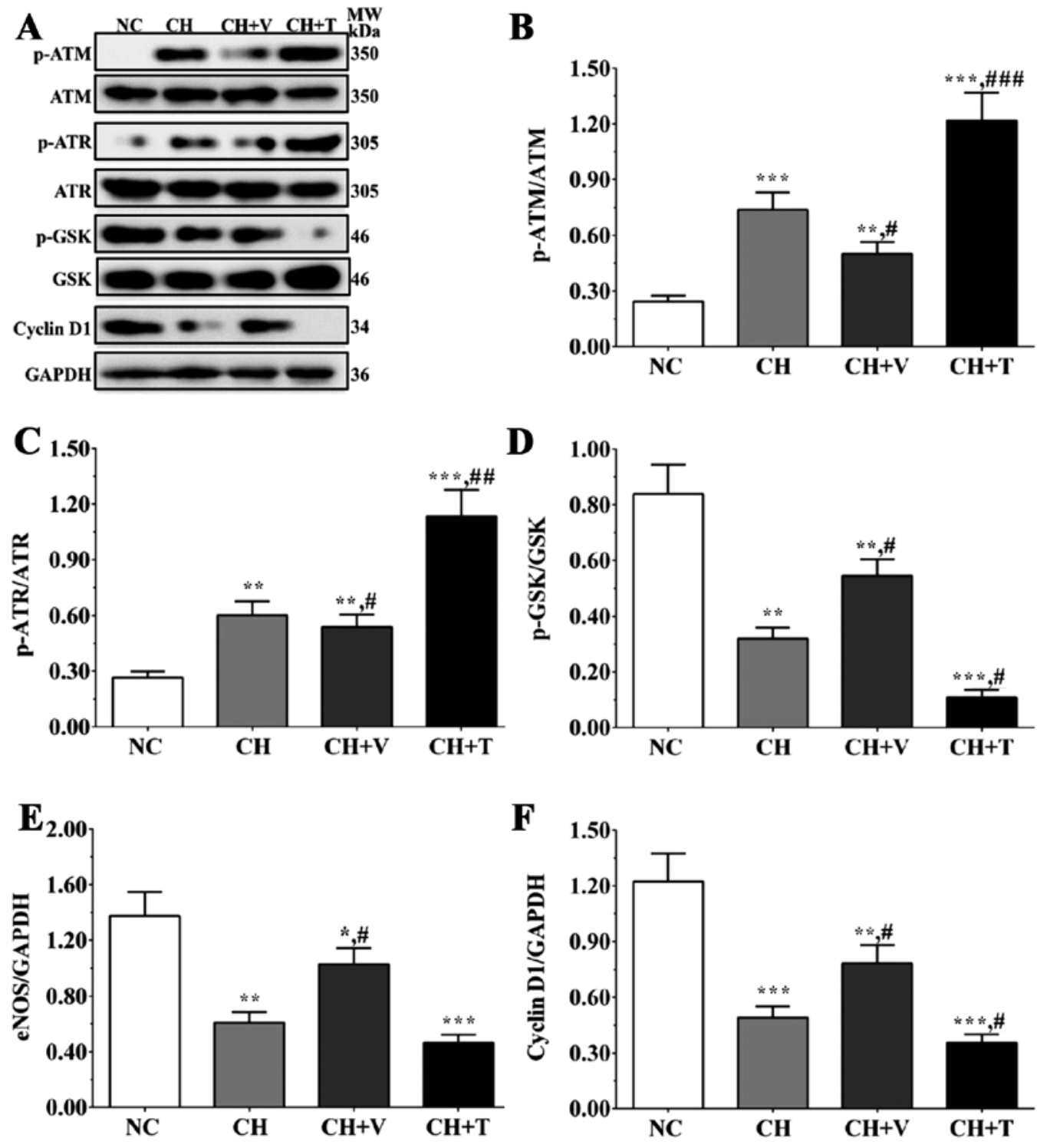

Figure 4. Expression levels of DNA damage-related molecules and cell cycle-related molecules. (A) Detection of expression levels of p-ATM, ATM, p-ATR, ATR, p-GSK, GSK and cyclin D1 using western blotting. (B-F) Quantitative analysis of the western blot results. Experiments were repeated three times independently. Data are represented as the mean $\pm \mathrm{SEM}$. ${ }^{*} \mathrm{P}<0.05,{ }^{* *} \mathrm{P}<0.01$ and ${ }^{* * *} \mathrm{P}<0.001$ vs. the $\mathrm{NC}$ group; ${ }^{\#} \mathrm{P}<0.05,{ }^{\# \#} \mathrm{P}<0.01$ and ${ }^{\# \# \#} \mathrm{P}<0.001$ vs. the CH group. GAPDH was used as an internal control. Each image of western blotting band was separated using a black rectangle. Groups: NC, negative control group; $\mathrm{CH}$, a cholesterol stimulation group; $\mathrm{CH}+\mathrm{T}$, cholesterol stimulation with TRAP-6 treatment group; $\mathrm{CH}+\mathrm{V}$, cholesterol stimulation with vorapaxar treatment group.

ratios of $\mathrm{p}$-ATM/ATM and $\mathrm{p}$-ATR/ATR were significantly increased in the cholesterol treatment groups compared with the $\mathrm{NC}$ group $(\mathrm{P}=0.001$ and 0.002 in the $\mathrm{CH}$ group, 0.003 and 0.004 in the $\mathrm{CH}+\mathrm{V}$ group, 0.001 and 0.001 in the $\mathrm{CH}+\mathrm{T}$ group) and were significantly decreased after vorapaxar treatment and significantly increased after TRAP-6 treatment in endothelial cells compared with the $\mathrm{CH}$ group $(\mathrm{P}=0.024$ and 0.046 in the $\mathrm{CH}+\mathrm{V}$ group, 0.001 and 0.005 in the $\mathrm{CH}+\mathrm{T}$ group). The ratios of $\mathrm{p}-\mathrm{GSK} / \mathrm{GSK}$ and the expression of cyclin D1 were significantly decreased after cholesterol treatment compared with the $\mathrm{NC}$ group $(\mathrm{P}=0.001$ and 0.001 in the $\mathrm{CH}$ group, 0.005 and 0.013 in the $\mathrm{CH}+\mathrm{V}$ group, 0.001 and 0.001 in the $\mathrm{CH}+\mathrm{T}$ group) and were significantly increased after vorapaxar treatment and significantly decreased after TRAP-6 treatment in endothelial cells compared with the $\mathrm{CH}$ group $(\mathrm{P}=0.022$ and 0.013 in the $\mathrm{CH}+\mathrm{V}$ group, 0.019 and 0.028 in the $\mathrm{CH}+\mathrm{T}$ group). The expression level of eNOS was significantly decreased after cholesterol treatment compared with the NC group $(\mathrm{P}=0.002$ in the $\mathrm{CH}$ group, 0.020 in the $\mathrm{CH}+\mathrm{V}$ group and 0.001 in the $\mathrm{CH}+\mathrm{T}$ group), and vorapaxar significantly increased eNOS expression compared with the $\mathrm{CH}$ group $(\mathrm{P}=0.018)$. These results indicate that cholesterol directly induced DNA damage in the endothelial cells and inhibited cell proliferation and that vorapaxar could alleviate these effects, serving a protective role in endothelial cells.

Immunofluorescence was used to measure the concentration of $\left[\mathrm{Ca}^{2+}\right]_{i}$. As shown in Fig. 5, we detected the concentration of intracellular $\mathrm{Ca}^{2+}\left(\left[\mathrm{Ca}^{2+}\right]_{\mathrm{i}}\right)$. The mean fluorescence intensity of the concentration of $\left[\mathrm{Ca}^{2+}\right]_{i}$ was $235.38 \pm 23.56$ in the $\mathrm{NC}$ group and was $62.92 \pm 9.23,162.42 \pm 19.33$ and $43.19 \pm 4.26$ in the $\mathrm{CH}$ group, the $\mathrm{CH}+\mathrm{V}$ group and the $\mathrm{CH}+\mathrm{T}$ group, respectively. These results indicated that cholesterol stimulation significantly decreased $\left[\mathrm{Ca}^{2+}\right]_{\mathrm{i}}$ compared with the NC group 

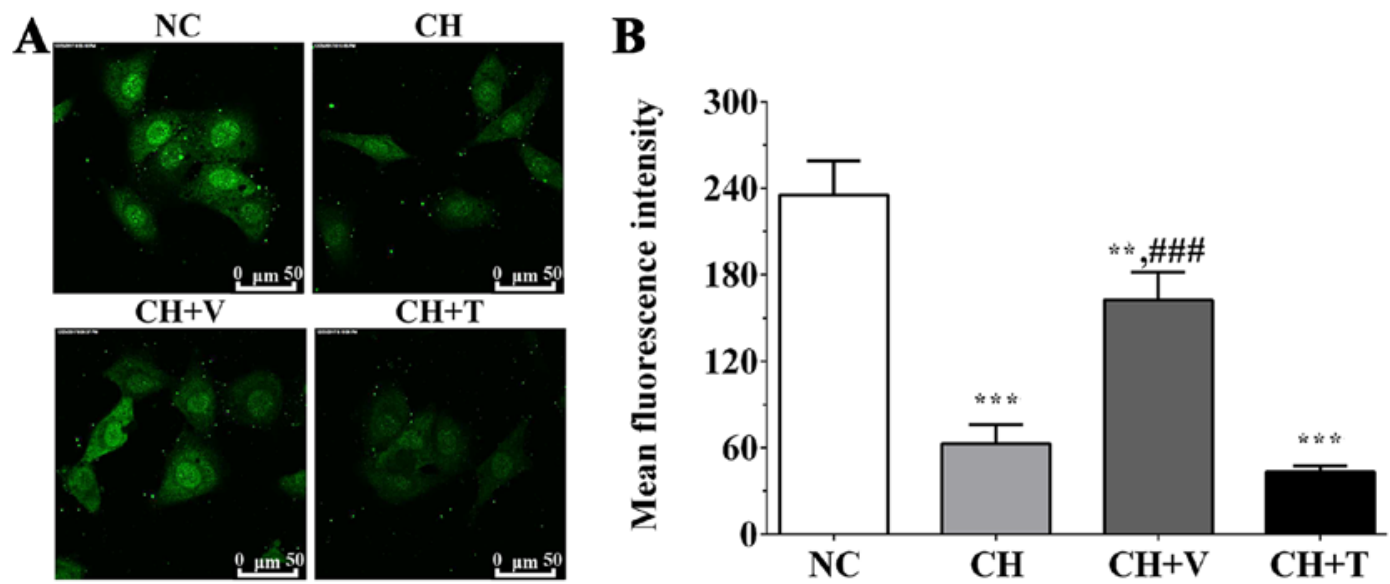

Figure 5. Detection of $\left[\mathrm{Ca}^{2+}\right]_{\mathrm{i}}$ using immunofluorescence. (A) Results of $\left[\mathrm{Ca}^{2+}\right]_{\mathrm{i}}$ using immunofluorescence. (B) Quantitative analysis of the immunofluorescence results. Experiments were repeated three times independently. Data are represented as the mean $\pm \mathrm{SEM}$. ${ }^{* *} \mathrm{P}<0.01$ and ${ }^{* * *} \mathrm{P}<0.001$ vs. the $\mathrm{NC}$ group;

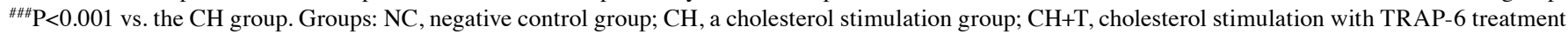
group; $\mathrm{CH}+\mathrm{V}$, cholesterol stimulation with vorapaxar treatment group.

$(\mathrm{P}=0.001$ in the $\mathrm{CH}$ group, 0.014 in the $\mathrm{CH}+\mathrm{V}$ group and 0.001 in the $\mathrm{CH}+\mathrm{T}$ group), and vorapaxar could significantly alleviate this trend compared with the $\mathrm{CH}$ group $(\mathrm{P}=0.001)$, whereas there was no significant change between the $\mathrm{CH}$ group and the $\mathrm{CH}+\mathrm{T}$ group.

\section{Discussion}

In the present study, cholesterol stimulation was found to activate the AKT/JNK signaling pathway, induce an inflammatory response and decrease the $\left[\mathrm{Ca}^{2+}\right]_{\mathrm{i}}$ in endothelial cells, and inhibit proliferation of endothelial cells. The inhibition of PAR-1 via vorapaxar was able to alleviate the effect of cholesterol on endothelial cells, whereas the activation of PAR-1 via TRAP-6 enhanced these effects. Therefore, we speculated that vorapaxar maintains the viability of endothelial cells and the permeability of the endothelial barrier via activation of the AKT/JNK signaling pathway, inhibition of the inflammatory response and a decrease in $\left[\mathrm{Ca}^{2+}\right]_{\mathrm{i}}$, resulting in a protective role in endothelial cells.

Cardiovascular disease (CVD) is a serious threat to public health and the economy worldwide. According to data acquired from the World Health Organization (WHO) in 2012 , cardiovascular disease caused more than 17 million deaths worldwide, accounting for over a $30 \%$ mortality rate, and cost more than $\$ 193$ billion for the treatment of these patients (14). Atherosclerosis (AS) is the leading cause of CVD and is an inflammatory-related disease characterized by the progressive accumulation of lipids and inflammatory cells in the intima of arteries, especially in high lipid states (15). High lipids induce injury of the endothelial barrier, further causing an inflammatory response and the formation of thrombus and recruitment of circulating monocytes attached to the injury site of the endothelial barrier (16). These processes induce the transformation of monocytes into macrophages and the adhesion of platelets, resulting in the proliferation of vascular smooth muscle cells (VSMCs) and leukocytes, promoting the formation of plaque (17). Disruption of the plaque may cause exposure of the thrombogenic substrates and initiating the coagulation cascade, resulting in the formation of thrombus and manifestations of atherosclerotic disease, even MI or sudden death.

According to our results, a high concentration of cholesterol inhibited the proliferation of endothelial cells, and using TRAP-6 or vorapaxar to activate or inhibit PAR-1 significantly decreased or increased the viability rate of the endothelial cells compared with the cholesterol treatment and control groups, indicating that cholesterol inhibits the growth of endothelial cells, while inhibition or activation of PAR-1 reduces or increases these trends. We also detected the expression levels of inflammation-related genes to evaluate the inflammation response level in endothelial cells after cholesterol stimulation. The response of endothelial cells to lipoproteins could initiate an inflammatory response at the atherosclerosis site, resulting in the activation and release of cytokines including IL-1 and TNF- $\alpha$ (18). These processes would attract monocytes to migrate to the injury site and take up lipoproteins, forming foam cells. IL-13 is a Th2 cytokine that is involved in regulating inflammatory responses and serves an anti-inflammatory effect via promoting monocyte/macrophage transformation into a M2a phenotype and alleviating inflammatory responses (19). As shown in Fig. 2, the expression levels of IL-1 $\beta$, TNF- $\alpha$ and IL- 8 were significantly increased after cholesterol stimulation and were alleviated or increased after PAR-1 was inhibited or activated. However, the expression level of IL-13 presented an opposite trend. These results indicated that cholesterol stimulation could activate the inflammatory responses in endothelial cells and PAR-1 serves an important regulatory role in the maintenance of inflammatory balance, and vorapaxar exhibits an endothelial cell protective effect via the inhibition of inflammatory responses.

Multiple signaling pathways are involved in inflammatory response, and nuclear factor (NF)- $\mathrm{B}$ serves an important role in the regulation of many genes in inflammatory responses at the transcription level (20). Other factors such as oxidative stress, hypoxia, and genotoxic stress could also activate $\mathrm{NF}-\kappa \mathrm{B}$ via mitogen-activated protein kinases (MAPKs) and phosphatidylinositol 3-kinase (PI3K)/AKT (21). DNA damage is closely related to the development of atherosclerosis; nuclear DNA (nDNA) damage and a lack of mitochondrial 
DNA (mtDNA) are commonly observed in circulating blood cells and plaque cells of coronary heart disease patients (22). Oxidative stress induced by high cholesterol is one of the main factors leading to DNA damage, and long-term exposure to risk factors of atherosclerosis including smoking, diabetes and especially hyperlipidemia, may lead to the production of reactive oxygen species (ROS) and further cause DNA damage in endothelial cells (23). DNA damage initiates the DNA damage response (DDR) to guarantee proliferation of normal cells through the induction of cell cycle arrest mechanisms. DNA damage, especially double-stranded DNA breaks (DSB), activates ataxia-telangiectasia mutated (ATM) and ataxia telangiectasia and $\operatorname{rad} 3$ related (ATR) (24). A previous study found that cholesterol overload induced DNA damage and activated ATM/ATR, and ATM/ATR may serve a protective role in this process (25). A previous study found that NEMO undergoes post-translational modifications including phosphorylation and ubiquitination regulated by ATM after DNA damage, and this process may be linked with activation of NF- $\kappa B$ (26). Activation of NF- $\mathrm{BB}$ is one of the cellular responses to maintain homeostasis after DNA damage. In this study, we found that vorapaxar may perform a protective role in endothelial cells under cholesterol stimulation via increasing the expression of NF- $\mathrm{kB}$.

Endothelial nitric oxide synthase (eNOS) is constitutively expressed in endothelial cells and is activated by flowing blood pressure or agonists. Nitric oxide (NO) is regulated mainly by endothelial NO synthase (eNOS) in endothelial cells and serves a protective role (27). NO synthesized by endothelial eNOS could be released into vascular smooth muscle cells (VSMCs) and induce vasodilatation of the vascular. The release of endothelial NO could also inhibit the aggregation and adhesion of platelets and further inhibit the formation of plaque. Endothelial function serves an important role in the maintenance of vascular integrity by regulating the production and activation of NO. The development of atherosclerosis is closely related to the dysfunction of NO synthesis in endothelial cells. Previous studies have found that the activity of endothelial NO is reduced in ApoE-KO mice, which may be due to the inhibition of eNOS production or eNOS bioactivity, resulting in accelerated formation of atherosclerosis in ApoE-KO mice (28). A previous study found that genetic depletion of AKT may lead to dysfunction of endothelial cells, reducing migration and survival of VSMCs, leading to atherosclerosis and coronary artery obstruction, resulting in the formation of plaque (29). The AKT signaling pathway serves an important role in the regulation of eNOS. AKT1 is a main subtype of the AKT family expressed in endothelial cells, and mediates the survival and migration of endothelial cells and serves an important role in angiogenesis and the regulation of vascular structure $(30,31)$. Multiple stimuli including vascular endothelial growth factor (VEGF) and cholesterol activate AKT in endothelial cells, resulting in phosphorylation of eNOS and promoting NO release. AKT could directly phosphorylate eNOS or interact with Hsp90, increasing the activity of eNOS or its sensitivity to $\left[\mathrm{Ca}^{2+}\right]_{\mathrm{i}}(32)$. Increasing $\left[\mathrm{Ca}^{2+}\right]_{\mathrm{i}}$ could induce the activation of eNOS and the production of $\mathrm{NO}$ via a $\mathrm{Ca}^{2+} / \mathrm{calmodulin}$ independent kinase II (CaMKII) dependent mechanism (33). Cholesterol stimulation inhibited the AKT/mTOR signaling pathway, further decreasing the expression levels of eNOS and $\left[\mathrm{Ca}^{2+}\right]_{\mathrm{i}}$, leading to a reduction of $\mathrm{NO}$ and reduced integrity of the endothelial cell barrier, promoting the formation of thrombi and atherosclerosis. We found that cholesterol could induce DNA damage and decrease the expression of eNOS via the AKT signaling pathway and $\left[\mathrm{Ca}^{2+}\right]_{\mathrm{i}}$, resulting in inhibition of endothelial cell proliferation, further causing destruction of the endothelial barrier. However, vorapaxar could alleviate these changes via inhibition of PAR-1 and serves a protective role in regulation of endothelial function.

AKT also participates in the regulation of the cell cycle via the JNK signaling pathway. AKT interacts with mitogen-activated protein kinase kinase kinase (MAPKKK) and inhibits c-jun N-terminal kinase (JNK), resulting in maintenance of cell survival. A previous study found that overexpression or inhibition of AKT function could increase or decrease the survival of cardiomyocytes (34). Cell survival and migration are important process in the maintenance of vascular structure, and the AKT signaling pathway serves a critical role in these biological activities. GSK3 is a substrate of AKT, and the inhibition of GSK leads to proliferation and survival of smooth muscle cells (SMCs) and sustained homeostasis of blood vascular walls (35). A previous study found that this process is related to the development of atherosclerosis, and an increase in SMC proliferation may lead to thickening of the vascular adventitia. Arterial injury could also increase the activity of the AKT signaling pathway, resulting in inactivation of GSK3 $\beta$ and the activation of multiple transcription factors. These factors increase glucose metabolism, glycogen, lipid and protein synthesis, and expression of other specific genes (36). The AKT signaling pathway also participates in the process of myocardial remodeling via the phosphorylation of GSK-3 3 . The phosphorylation of AKT is the active form of AKT, whereas the phosphorylation of GSK-3 $\beta$ would inhibit its activity. A previous study found that activation of AKT is important in remote conditioning of myocardial cells and serves a protective role. This effect was displayed via inhibition of GSK-3 $\beta$ and protects myocardial cells from ischemia-reperfusion injury (37). A previous study also found that inhibition of GSK-3 $\beta$ increased the concentration of glucose in skeletal muscles, which may increase the survival of cardiac muscle (38). Connexin 43, also known as gap junction $\alpha-1$ (GJA-1), is critical for gap junctions between cells, allowing intercellular communication and physiological impulses to occur via junctions between cells. A previous study found that phosphorylation of connexin 43 was parallel to increasing gap junctions in a rat hypoxic model and serves a protective role in myocardial cells (39). The results of this study indicated that downstream molecules of the AKT signaling pathway, such as GSK- $3 \beta$ and connexin 43 , also participate in the cardio-protective function of AKT via maintaining endothelial cell survival and cellular junctions and protect endothelial cells from injury induced by cholesterol stimulation.

The present study indicated that a high concentration of cholesterol causes an inflammatory response and DNA damage in endothelial cells, inhibits the survival of endothelial cells and the release of $\mathrm{NO}$, leading to destruction of the endothelial barrier and formation of thrombi, and vorapaxar reverses these processes and serves a protective role in endothelial cells. 
However, more clinical experiments are needed, and we are collecting clinical samples to perform more experiments to support the findings of the present study.

\section{Acknowledgements}

Not applicable.

\section{Funding}

This research was supported by Zhejiang medical and health science and technology project (Grant no.2016KYA197).

\section{Availability of data and materials}

The datasets used and/or analyzed during the current study are available from the corresponding author on reasonable request.

\section{Authors' contributions}

JLP and PYH collected the samples and performed the experiments. JWW and JSJ collected and analysed the data. JLP and JFL designed the study and wrote the manuscript. All authors read and approved the manuscript and agree to be accountable for all aspects of the research in ensuring that the accuracy or integrity of any part of the work are appropriately investigated and resolved.

\section{Ethics approval and consent to participate}

All experimental protocols were approved by the Institutional Review Board of Tiantai People's Hospital of Zhejiang Province (Zhejiang, China).

\section{Patient consent for publication}

Not applicable.

\section{Competing interests}

The authors declare that they have no competing interests.

\section{References}

1. Badimón L, Vilahur G and Padró T:Lipoproteins, platelets and atherothrombosis. Rev Esp Cardiol 62: 1161-1178,2009(In English,Spanish).

2. Mehta D and Malik AB: Signaling mechanisms regulating endothelial permeability. Physiol Rev 86: 279-367, 2006.

3. Jennings LK: Mechanisms of platelet activation: Need for new strategies to protect against platelet-mediated atherothrombosis Thromb Haemost 102: 248-257, 2009.

4. Schaff M, Gachet C and Mangin PH: Anti-platelets without a bleeding risk: Novel targets and strategies. Biol Aujourdhui 209: 211-228, 2015 (In French)

5. Alberelli MA and De Candia E: Functional role of protease activated receptors in vascular biology. Vascul Pharmacol 62: 72-81, 2014.

6. Gryka RJ, Buckley LF and Anderson SM: Vorapaxar: The current role and future directions of a novel protease-activated receptor antagonist for risk reduction in atherosclerotic disease. Drugs R D 17: 65-72, 2017.

7. Machida T, Dohgu S, Takata F, Matsumoto J, Kimura I, Koga M, Nakamoto K, Yamauchi A and Kataoka Y: Role of thrombin-PAR1-PKC $\theta / \delta$ axis in brain pericytes in thrombin-induced MMP-9 production and blood-brain barrier dysfunction in vitro. Neuroscience 350: 146-157, 2017.
8. Suvorava T, Nagy N, Pick S, Lieven O, Rüther U, Dao VT, Fischer JW, Weber M and Kojda G: Impact of eNOS-dependent oxidative stress on endothelial function and neointima formation. Antioxid Redox Signal 23: 711-723, 2015.

9. Abeyrathna P and Su Y: The critical role of Akt in cardiovascular function. Vascul Pharmacol 74: 38-48, 2015.

10. Jin X, Xu Z, Fan R, Wang C, Ji W, Ma Y, Cai W, Zhang Y, Yang N, Zou S, et al: HO-1 alleviates cholesterol-induced oxidative stress through activation of Nrf2/ERK and inhibition of PI3K/AKT pathways in endothelial cells. Mol Med Rep 16: 3519-3527, 2017.

11. Khoufache K, Berri F, Nacken W, Vogel AB, Delenne M, Camerer E, Coughlin SR, Carmeliet P, Lina B, Rimmelzwaan GF, et al: PAR1 contributes to influenza A virus pathogenicity in mice. J Clin Invest 123: 206-214, 2013.

12. Pandey A, Chakraborty S and Chakraborty N: Nuclear proteome: Isolation of intact nuclei, extraction of nuclear proteins, and 2-DE analysis. Methods Mol Biol 1696: 41-55, 2018.

13. Livak KJ and Schmittgen TD: Analysis of relative gene expression data using real-time quantitative PCR and the 2(-Delta Delta C(T)) method. Methods 25: 402-408, 2001 .

14. Shi Z, Bielecka-Dabrowa AM, Mynbaev OA and Wei S: Find the essence through the phenomena: Cardiovascular diseases and biomarkers. Dis Markers 2018: 1929106, 2018.

15. Raggi P, Genest J, Giles JT, Rayner KJ, Dwivedi G, Beanlands RS and Gupta M: Role of inflammation in the pathogenesis of atherosclerosis and therapeutic interventions. Atherosclerosis 276: 98-108, 2018.

16. Liu H, Yu X, Yu S and Kou J: Molecular mechanisms in lipopolysaccharide-induced pulmonary endothelial barrier dysfunction. Int Immunopharmacol 29: 937-946, 2015

17. Yi X, Lin J, Luo H, Wang C and Liu Y: Genetic variants of PTGS2, TXA2R and TXAS1 are associated with carotid plaque vulnerability, platelet activation and TXA2 levels in ischemic stroke patients. PLoS One 12: e0180704, 2017.

18. Li K, Ching D, Luk FS and Raffai RL: Apolipoprotein E enhances microRNA-146a in monocytes and macrophages to suppress nuclear factor- $\kappa \mathrm{B}$-driven inflammation and atherosclerosis. Circ Res 117: e1-e11, 2015.

19. Solís-Martínez R, Cancino-Marentes M, Hernández-Flores G, Ortiz-Lazareno P, Mandujano-Álvarez G, Cruz-Gálvez C, Sierra-Díaz E, Rodríguez-Padilla C, Jave-Suárez LF, Aguilar-Lemarroy A and Bravo-Cuellar A: Regulation of immunophenotype modulation of monocytes-macrophages from M1 into $\mathrm{M} 2$ by prostate cancer cell-culture supernatant via transcription factor STAT3. Immunol Lett 196: 140-148, 2018.

20. Chen X, Zong C, Gao Y, Cai R, Fang L, Lu J, Liu F and Qi Y: Curcumol exhibits anti-inflammatory properties by interfering with the JNK-mediated AP-1 pathway in lipopolysaccharideactivated RAW264.7 cells. Eur J Pharmacol 723: 339-345, 2014.

21. Moniruzzaman M, Ghosal I, Das D and Chakraborty SB: Melatonin ameliorates $\mathrm{H}_{2} \mathrm{O}_{2}$-induced oxidative stress through modulation of Erk/Akt/NFkB pathway. Biol Res 51: 17, 2018.

22. Gray K and Bennett M: Role of DNA damage in atherosclerosis-bystander or participant? Biochem Pharmacol 82: 693-700, 2011.

23. Janssens $\mathrm{S}$ and Tschopp J: Signals from within: The DNA-damage-induced NF- $\kappa$ B response. Cell Death Differ 13: 773-784, 2006.

24. Maréchal A and Zou L: DNA damage sensing by the ATM and ATR kinases. Cold Spring Harb Perspect Biol 5: a012716, 2013.

25. Enríquez-Cortina C, Bello-Monroy O, Rosales-Cruz P, Souza V, Miranda RU, Toledo-Pérez R, Luna-López A, Simoni-Nieves A, Hernández-Pando R, Gutiérrez-Ruiz MC, et al: Cholesterol overload in the liver aggravates oxidative stress-mediated DNA damage and accelerates hepatocarcinogenesis. Oncotarget 8: 104136-104148, 2017.

26. Miyamoto S: Nuclear initiated NF- $\mathrm{NB}$ signaling: NEMO and ATM take center stage. Cell Res 21: 116-130, 2011.

27. Sakata K, Kondo T, Mizuno N, Shoji M, Yasui H, Yamamori T, Inanami $\mathrm{O}$, Yokoo $\mathrm{H}$, Yoshimura $\mathrm{N}$ and Hattori Y: Roles of ROS and PKC- $\beta$ II in ionizing radiation-induced eNOS activation in human vascular endothelial cells. Vascul Pharmacol 70: 55-65, 2015.

28. Vechoropoulos M, Ish-Shalom M, Shaklai S, Sack J, Stern N and Tordjman KM: The proatherogenic effect of chronic nitric oxide synthesis inhibition in ApoE-Null mice is dependent on the presence of PPAR $\alpha$. PPAR Res 2014: 124583, 2014.

29. Fernández-Hernando C, Ackah E, Yu J, Suárez Y, Murata T, Iwakiri Y, Prendergast J, Miao RQ, Birnbaum MJ and Sessa WC: Loss of Akt1 leads to severe atherosclerosis and occlusive coronary artery disease. Cell Metab 6: 446-457, 2007. 
30. Somanath PR, Razorenova OV, Chen J and Byzova TV: Akt1 in endothelial cell and angiogenesis. Cell Cycle 5: 512-518, 2006.

31. Fulton D, Gratton JP, McCabe TJ, Fontana J, Fujio Y, Walsh K, Franke TF, Papapetropoulos A and Sessa WC: Regulation of endothelium-derived nitric oxide production by the protein kinase Akt. Nature 399: 597-601, 1999.

32. Shin MK, Jeong KH, Choi H, Ahn HJ and Lee MH: Heat shock protein 90 inhibitor enhances apoptosis by inhibiting the AKT pathway in thermal-stimulated SK-MEL-2 human melanoma cell line. J Dermatol Sci 90: 357-360, 2018.

33. Wang B, Zhao J, Yu M, Meng X, Cui X, Zhao Y, Zhu Y, Xing W and Guan Y: Disturbance of intracellular calcium homeostasis and CaMKII/CREB signaling is associated with learning and memory impairments induced by chronic aluminum exposure. Neurotox Res 26: 52-63, 2014.

34. Sugishita Y, Leifer DW, Agani F, Watanabe M and Fisher SA: Hypoxia-responsive signaling regulates the apoptosis-dependent remodeling of the embryonic avian cardiac outflow tract. Dev Biol 273: 285-296, 2004.

35. Park KW, Yang HM, Youn SW, Yang HJ, Chae IH, Oh BH, Lee MM, Park YB, Choi YS, Kim HS and Walsh K: Constitutively active glycogen synthase kinase-3 $\beta$ (GSK-3 $\beta$ ) gene transfer sustains apoptosis, inhibits proliferation of vascular smooth muscle cells, and reduces neointima. Arterioscler Thromb Vasc Biol 23: 1364-1369, 2003.
36. Nakae J, Park BC and Accili D: Insulin stimulates phosphorylation of the forkhead transcription factor FKHR on serine 253 through a wortmannin-sensitive pathway. J Biol Chem 274: 15982-15985, 1999.

37. Rahman S, Li J, Bopassa JC, Umar S, Iorga A, Partownavid P and Eghbali M: Phosphorylation of GSK-3 $\beta$ mediates intralipid-induced cardio-protection against ischemia/reperfusion injury. Anesthesiology 115: 242-253, 2011.

38. Forde JE and Dale TC: Glycogen synthase kinase 3: A key regulator of cellular fate. Cell Mol. Life Sci 64: 1930-1944, 2007.

39. Brandenburger T, Huhn R, Galas A, Pannen BH, Keitel V, Barthel F, Bauer I and Heinen A: Remote ischemic preconditioning preserves Connexin 43 phosphorylation in the rat heart in vivo. J Transl Med 12: 228, 2014.

This work is licensed under a Creative Commons Attribution-NonCommercial-NoDerivatives 4.0 International (CC BY-NC-ND 4.0) License. 